\title{
THE HISTORIOGRAPHIC REVIEW OF THE HISTORY OF FORMATION AND ACTIVITY OF TURKESTAN STATISTICAL SERVICE
}

\author{
Tanzilya Ravilevna Khamrayeva \\ Candidate of Historical Sciences (PhD), Docent, Head of the Department of "World History" \\ of Andizhan State University, Andizhan region, Republic of Uzbekistan
}

Article DOI: https://doi.org/10.36713/epra9604

DOI No: 10.36713/epra9604

\begin{abstract}
This article analyses research works devoted to the issue of studying of the history of formation and activities of the statistical service of Turkestan. Besides, in this research the main positions of modern source studies and historiography received scientific justification. Consider this on the example of the history of the creation and activities of the statistical service in Turkestan.
\end{abstract}

KEY WORDS: statistics, source, information, statistical materials, committee, research, colonial policy, science, review, history.

\section{INTRODUCTION}

The transformation of the scientific positions of historians towards an objective, truthful presentation of historical events, the disclosure of bypassed problems of source studies and historiography, has become a significant achievement of historical thought in post-Soviet society. As a result, the main positions of modern source studies and historiography received scientific justification. Consider this on the example of the history of the creation and activities of the statistical service in Turkestan.

\section{RESEARCH METHODS}

Our historiography does not yet contain a summary essay characterizing the activities of the statistical committees, although it is of undoubted interest to workers in the social sciences, since these committees paid much attention to the study of the economic life of the cultural history of the peoples of Central Asia.

\section{RESULTS AND DISCUSSIONS}

The whole layer of research, reflecting certain facets of the issue under study, is subdivided in the problemchronological order into the following groups: 1) works published during the colonial period; 2) research literature of the Soviet period; 3) publications of the period of independence. The publications included in the first group contain primary information about the history of the formation and activities of statistical committees in Turkestan and allow you to create a personal idea of the era of the emergence and development of statistics and related processes. Of greatest interest in this respect are the works of A.V. Bunyakovsky, M.A. Terentiev, N.I. Malakhovskii. The most valuable and significant event is the publication of the book by A.V. Bunyakovsky [1]. ("On the space and population of the Turkestan region"). In the process of conquering Central Asia, the Russian authorities began a comprehensive study of the region, with the main attention being paid to issues of military strategic importance geography and topography, the state of communications, description of roads, passes, bridges, collecting information for compiling maps of the region. These include the works of: N. Maev "Essays of the Bukhara Khanate" [2, 77-328].

A. Galkin "A brief military and statistical essay of an officer of the General Staff of the TVO in 1889 in the Bukhara Khanate and in the southern part of the Samarkand region" [3, 1-47]; "Materials for the statistical description of the Ferghana region. The results of land-tax works", "Military-statistical description of the Turkestan military 


\section{SJIF Impact Factor 2021: 8.013| ISI I.F.Value:1.241| Journal DOI: 10.36713/epra2016 ISSN: 2455-7838(Online) EPRA International Journal of Research and Development (IJRD) Volume: 7 | Issue: 2 | February 2022 - Peer Reviewed Journal}

district", etc. The study of the historiography of the issue allows us to highlight the three-volume work of the military historian M.A. Terentyev [4]. The work was written on the basis of an analysis of documents on the history of aggressive actions and the political and administrative structure of Turkestan, documents of the Turkestan military district, the Office of the Turkestan Governor General and the Military Ministry of the Russian Empire. The work is supplied with applications - military topographic maps of the region, statistical materials and biographical information about people who collected information on statistics. During the colonial period, a number of studies appeared related to the coverage of the economic life of Turkestan, in particular, the Ferghana region, based on the materials of the regional statistical committees. The authors of these studies [5]: V.I. Masalsky, N.P. Fedorov, A. Stetkevich, A.I. Shakhnazarov, V.I. So, N.I.Malakhovsky in his work, based on the data of statistical committees, presented information about the wealth exported from the region [6]. This approach is also typical for the work of S.I. Gulishambarov [7].

On the basis of statistical materials, they analyzed: the economic state of the region, its productive forces, agriculture, domestic and foreign trade, the state of industry. The state of the cotton-cleaning industry is described in particular detail and forecasts are given regarding its further development. From the theoretical works of Russian scientists of the second half of the XIX - early XX centuries. especially important were special courses and textbooks on the theory of statistics, developed by professors of universities and other higher educational institutions in Russia. They contributed to the formation of views on the statistics of more than one generation of practitioners in this field. The most prominent representative of Russian statistical science in the second half of the $19^{\text {th }}$ century was Yu.E. Yanson, a professor at St. Petersburg University. The author of numerous works, he deserved special recognition of his contemporaries, thanks to his university course on the theory of statistics, published in 1885 and for many decades served as the main textbook in higher educational institutions [8]. Among the scientists of the first group, professors A.I. Chuprov (1842-1908). They were directly involved in statistical surveys and in their work many questions of statistical theory were solved on the basis of the experience of statistical research. So, the statistical science of the second half of the XIX - early XX centuries. made significant progress in its development. Russian scientists contributed quite a lot of new things to the development of its theory, and the idea of statistics as a social science was not only recognized, but was also significantly developed in the works of its most prominent figures. The second group includes the historiography of the Soviet period, in which the "class" approach, based on Marxist-Leninist theory, reigned supreme. The class approach to the problem under study gave rise to a tendentious and one-sided coverage of it in Soviet historiography and led to the appearance of falsified statistical data on population, local and general censuses, on calculations of national income per capita, etc.

Nevertheless, the informational and scientific significance of literature Soviet period is ambiguous. For this work, the works of the famous economist A.P. Demidov [10], published in the $20 \mathrm{~s}$ of the $20^{\text {th }}$ century, were of great interest. Using the materials of the official reports of the colonial authorities, he highlighted issues related to the development of the cotton industry, cotton trade and industry in Turkestan. In the 1920s, a number of works were published: G. Safarov, T. Ryskulov, P. G. Galuzo, V. Lavrentiev [11]. They covered the situation of the indigenous population of Turkestan, the "bourgeois colonization" of the region, the socio-economic situation of the Turkestan village; gave a description of the colonial system of power, individual Russian institutions and government agencies and exposed the negative consequences of Russia's colonial policy.

Since the mid-1930s, the leading trend in historiography over the period under study has been its total politicization, which has led to the fact that the social sciences have practically lost their original functions. Their relative revival began only in the mid-1950s, which was facilitated by the partial removal of the secrecy regime in the archives and the expansion of researchers' access to documentary sources. From the standpoint of this concept in the $60 \mathrm{~s}-80 \mathrm{~s}$ of the twentieth century. a number of fundamental works on the history of colonial Turkestan were published, which made a certain contribution to the enrichment of the source base of the problem. In the studies of A. Aminov, M. P. Vyatkin, A. P. Savitsky, A. S. Sadykov, A. Yuldashev, N. A. Khalfin, H. Z. Ziyaev, M. I. Vekselman and others, the key directions of the history of the tsarist colonization of Turkestan and Central Asia as a whole. Despite the new concept, they focused their attention on topical issues of the socio-economic situation in the region and the negative consequences of joining Central Asia to Russia. A detailed analysis of the most subordinate reports of the governors was carried out by B.G. Litvak [12].

A special place in the work of the researcher is occupied by the analysis of statistical applications to reports and the determination of the degree of reliability of this source. V.A.Berlinskikh studied the activities of provincial statistical committees in the context of the development of Russian historical science [13]. The author analyzed the phenomenon of provincial historiography and showed the participation of statistical committees in its formation. He paid special attention to the leading role of the secretary of the committee, as the organizer of scientific research in the province. In the studies of N.M. Balatskaya and L.I. Razdorsky [14], the history of creation, structure and 


\section{SJIF Impact Factor 2021: 8.013| ISI I.F.Value:1.241| Journal DOI: 10.36713/epra2016 ISSN: 2455-7838(Online) EPRA International Journal of Research and Development (IJRD) Volume: 7 | Issue: 2 | February 2022 - Peer Reviewed Journal}

informative possibilities of the "Commemorative Books" published by provincial statistical committees are considered. A general review of publications of provincial statistical committees is presented in the work of A.P. Shpak [15, 3840]. Particular attention is paid to the study of the development of book publishing in the Russian provinces and the role of provincial statistical committees in the development of cultural life in the provinces. The publishing activity of the statistical committees of the Turkestan region is described by B.V. Lunin [16, 30-39]. In the article "From the history of the activities of the statistical committees of the Turkestan region" the author showed the role of statistical committees in collecting and studying materials on the nature, economy, culture and history of Turkestan. Particular attention is paid to regional surveys with detailed information about the national economy, irrigation systems, communication routes, taxes and taxes, health care and education. Such aspects of local history activities of regional committees as archaeological research, protection of historical and cultural monuments and publishing were studied by I.I. Komarova [17, 11-12].

The study by I.I.Komarova is devoted to the characteristics of the main areas of activity of regional committees. The author pays special attention to such aspects of local lore activities of committees as archaeological research, protection of historical and cultural monuments, and publishing. I.I.Komarova, on the basis of a comprehensive analysis of various types of publications, showed the illegitimacy of the opinion established in historiography about the low quality of scientific works of committees. The article by A.Kh. Ayubzhanov [18, 52-60] examines the socio-economic activities of statistical committees. Information on the history of statistics is also reflected in the works of foreign researchers. So J.V. Nixon [19] studied the issues of international comparability of statistical data, the project of creating an international statistical organization (International Statistical Institute, ISI), and the role of Russian statisticians P.P.Yanson in the organization of the International Statistical Institute. The work of Corrado Gini [20] shows the process of development of statistical methodology; its application to various branches of the social sciences (demography, economics, trade).

Decisive changes in the nature and methodology of scientific knowledge were determined in Uzbekistan after gaining independence, when it became possible to create works in a new conceptual key, based on scientific principles generally accepted in world historical science. Among the works of the third group, covering from new methodological positions the issues of the colonial and socio-economic policy of the Russian Empire, it is necessary to name the works of N.A. Abdurakhimova, D.A. Alimova, F.B. Iskhakov, Sh.S. Gafforova, G.A. Akhmedzhanova and others [21]. The monograph by N.A. Abdurakhimova reflects the essence, characteristics and features of the colonial system of power in Turkestan, the specifics of the relationship between the system and Turkestan society, the history of state institutions, the role of Russian bureaucracy in pursuing colonial policy. F.B. Iskhakov showed the imperial practice of implementing the national policy of the colonial power in Turkestan, including in the aspects of economic transformations aimed at exploiting the economy and the masses in the interests of the metropolis. Sh.S. Gaffarov, revealing in his monograph the problem of the resettlement policy of the Russian Empire in Turkestan, used the statistical data of the Samarkand, Syrdarya and Ferghana governments and conducted a comparative analysis using other types of sources. In the work of N.U. Musaev, from new methodological positions, the process of formation of industrial production in the regions of the Turkestan region, including the Ferghana region, is shown. In the second chapter of N.R. Makhkamova's dissertation work, the transformation of the social stratification of society is analyzed in a historical retrospective, and the directions of the social composition of the society of the indigenous population of Turkestan after the conquest by the Russian Empire are identified [22]. All the above-mentioned works testify to the fact that a huge layer of publications has appeared, distinguished by the novelty of methodological approaches and a new reading of historical sources.

\section{CONCLUSION}

At the same time, the analysis of these works shows that with all the variety of problems raised by scientists of the republic, the topic of creating a statistical service in Turkestan and its activities in the late XIX - early XX centuries. remains little studied. Unfortunately, an integral study has not been created that would comprehensively study the history of the formation and activities of the statistical service in Turkestan with its characteristic general and special tendencies.

\section{REFERENCES}

1. Bunyakovsky A.V. On the space and population of the Turkestan region. - St. Petersburg: B.I., 1873. - 238 p.

2. Maev N. Essays on the Bukhara Khanate //Materials for statistics of the Turkestan region. - St. Petersburg, 1879. Issue. V. - p. 77 - 328.

3. Galkin A. A brief military-statistical essay of an officer of the General Staff of the TVO in 1889 in the Bukhara Khanate and in the southern part of the Samarkand region // SMA. - SPb., 1894. Issue. IVII. - P.1 - 47.

4. Terentiev M.A. History of the conquest of Central Asia. T. I - III. - St. Petersburg, 1906.

5. Masalsky V.I. Cotton business in Central Asia. - St. Petersburg: B.I., 1892. - 166 p.; Fedorov N.P. Cotton growing in Central Asia. - St. Petersburg: B.I., 1898. Stetkevich. A. Is Turkestan unprofitable for Russia. - St. Petersburg: B.I., 1899; - 276 p. Shakhnazarov A.I. 


\section{SJIF Impact Factor 2021: 8.013| ISI I.F.Value:1.241| Journal DOI: 10.36713/epra2016 ISSN: 2455-7838(Online) EPRA International Journal of Research and Development (IJRD)

Agriculture in the Turkestan region. - St. Petersburg: B.I., 1908. - 512 p.; Oglobin V.I. Industry and trade of Turkestan. - M.: B.I., 1914. - 187 p.

6. Malakhovskiy N.I. Productive forces of Turkestan. - St. Petersburg: B.I., 1909. - 313 p.

7. Gulishambarov S.I. Economic overview of the Turkestan region served by the Central Asian Railway. Part 1. Askhabad: B.I., 1913. - 176 p.

8. Yanson Yu E. Theory of statistics. - St. Petersburg: B.I., 1913. $-615 p$.

9. Chuprov A.I. The theory of statistics and population statistics. - M.: B.I., 1899. - 369 p.; his own. Statistics. St. Petersburg, 1907. - 276 p.; Kablukov N. A. Theory and methods of statistics. - St. Petersburg, 1911. - 177 p. (5th edition, 1922); Fortunatov A.F. On statistics. - St. Petersburg: B.I., 1907. - 271 p. (The 3rd edition was made in 1921).

10. Demidov A.P. Economic essays on cotton growing, cotton trade and industry of Turkestan. - M.: Center. ex. press of the Supreme Economic Council of the USSR, 1926. - 249 $p$.

11. Safarov G. Colonial revolution (Experience of Turkestan). - M.: Gosizdat, 1921. - 147 p.; Ryskulov T. Revolution and the indigenous population of Turkestan. (Collection of the most important articles, reports, speeches and theses). Part 1. 1917 - 1919. - Tashkent: State Publishing House, 1925. - 218 p.; Galuzo P.G. Turkestan is a colony. (Essay on the history of Turkestan from the conquest by the Russians to the revolution of 1917). - M.: Kom. Un-t labor. East, 1929. - 164 p.; Lavrentyev V. Capitalism in Turkestan. (Bourgeois colonization of Central Asia). - L.: A.N.SSSR, 1930. - 185 p.

12. Litvak B.G. Essays on source studies of mass documentation. - M: Nauka, 1979. - 235 p.

13. Berlinskikh V.A. District historians: Russian provincial historiography. - M.: New Literary Review, 2003. - 528 p.

14. Balatskaya N.M., Razdorsky L.I. Commemorative books of provinces and regions of the Russian Empire (1836 1917). preliminary list. - St. Petersburg, 1994. - 148 p.

15. Shpak A.P. The role of provincial statistical committees in the development of book publishing in the Russian provinces (mid-1850s - early 1880s) // Research and Materials. Collection. - M., 1986. Issue. 53. - p. 38-40.

16. Lunin B.V. From the history of the activities of the statistical committees of the Turkestan region // Social sciences in Uzbekistan. Issue 6. - Tashkent. 1962. - p. 30 39.

17. Komarova I.I. Scientific and historical activity of provincial and regional statistical committees // Archeographic Yearbook. - M., 1978. - S. 11 - 12.

18. Ayubzhanov A.Kh. On the activities of the Turkestan Statistical Committee // Issues of statistical study of social and economic phenomena. - M., 1982. p. 52 - 60.

19. Nixon J. W. A history of the international statistical institute 1885 - 1960. - The Hague, 1960. - 132 p.

20. Corrado Gini. La logica nella statistica. - Paolo Boringhleri, 1962. - 126 p.

21. Abdurakhimova N. A., Rustamova G. The colonial system of power in Turkestan in the second half of the 19th - the first quarter of the 20th century. - Tashkent: University, 1999. - 162 p.; Alimova D. History as history, history as science. T.1. History and historical consciousness. Tashkent: Uzbekistan, 2008. - 280 p.; Iskhakov F. B. Central Asia and Russia in the 18th - early 20th centuries. - Tashkent, 2009. - 291 p.; Gafforov. Sh. S. History and fate - Tashkent: Fan, 2006. - $223 \mathrm{~b}$. Akhmedzhanov G. Russia and Central Asia. Relationship in historical development. - M. - Tashkent: Radugaprint, 2008. - $183 p$.

22. Musaev N.U. Formation and development of industrial production in Turkestan (late XIX - early XX centuries): Abstract of the thesis of Doctor of Historical Sciences. Tashkent, 1999. - 58 p. Makhkamova N.R. The social structure of society on the territory of Uzbekistan: traditions and transformations (late 19th - 30s of the 20th century): Abstract of the thesis of Doctor of Historical Sciences. - Tashkent, 2009. - 50 p. 